\title{
INCULCATE MORAL VALUES IN CHILDRENS THROUGH EDUCATION
}

KEY WORDS: Children,

Education, Moral Values.

\section{Surojit Das*}

\section{Rimpa Porel}

Research Scholar (Ph.D), Ramakrishna Mission Sikshanamandira, Belur Math, Howrah, W.B. *Corresponding Author

Research Scholar (Ph.D), Kazi Nazrul University, Asansol, Paschim Burdwan, W.B.

터 The aim of achievement a peaceful life and a well constructed society are to be success through development of moral values among individual. Moral values by which individual manage their violent tendencies. In this era man is victim of violence, self-interest which hamper in achieve harmonious life caused by lack of moral values. By developing moral values among children they can walk to the right path. Education is a process by which moral values could properly install in children. In this article attempt has been made to find out proper ways of education to inculcate moral values among children.

\section{I.INTRODUCTION:}

"If wealth is lost nothing is lost"

"If health is lost something is lost"

"If character is lost everything is lost"-M.K. Gandhi.

Everybody knows that life is precious, life is important. Every one protects his life because we care for it more than anything else. Character is most important part of one's life. Character is the basis of one's self development. Character formation is the development of various traits such as honesty, purity, perseverance, sincerity, faith, obedience, humanistic attitude etc.Values are very important for building a good character of a person and for better society also. Values are guidelines, standards of behavior which are desirable for a specific society during which an individual lives. Moral values are answerable for the all spherical development of an individual. Values are backbone of human personality, human society and nation. Moral values can create joyful environment, peaceful mind, best quality of life, sustainability, etc. If we improve ourselves, we can construct a good society for us. No one is a born as a spoilt person. Environment is that the main issue for deviating the kids' way of taking the right path. Education is a process in which developed ones personality and not only for gaining certificates and skills. Education is a way to inculcate moral value in children. By education we can form our character. Educational institution and home can provide some moral lesion to children, such as respect elders, always the right thing should be done, never speak lies, love your country, love for good human being, don't be jealous etc.

The aim of education is followed by philosophical, social, political, cultural norms of society. Education must be able to preserve the social, cultural, heritage as well as social reconstruction. Education is multipurpose system not only inculcate political, social, cultural awareness in children, but also a medium for promoting moral value in humanity. The educational institution must focus on imparting moral values in the children. Teachers must give special effort to help children imbibe good moral values. Inculcating good moral values in children is as important as teaching them other subject because they are the future of a nation. A great Indian philosopher like Swami Vivekananda, Rabindranath Tagore, Mahatma Gandhi, Dr. S. Radha Krishnan, and Dr. A. P. J. Abdul Kalam, who might prefer that education while not ethical values would result in clutter, giddiness, and mental in addition as social disorders.

\section{Objectives of the study}

1. To promote moral values among children through education.

2. In this study, we focus on the role of family, school, teachers to enhancing student's moral values.

\section{Methodology}

Qualitative method (Documentary analysis) has been used in this study.

\section{Sources used}

The paper is based on the secondary information collected from different source like research journals, books and website etc.

\section{v. Concept of values and moral values}

The word value springs from Latin word 'Valerie' which suggests strong and vigorous. According to Oxford dictionary, 'Value' means 'Worth'. Values are the socially acceptable norms to assess someone, object or any situation. According to the dictionary, values are things that have an intrinsic worth in usefulness or importance to the principles, standards, or qualities thought worthy or desirable.

Hill (2004) said that values are the priorities individuals and societies attach to certain beliefs, experiences, and objects, choose how they shall live and what they shall treasure.

According to Hall (1994) values are the ideals that give significance to our lives that are mirrored through the priorities that we elect which we tend to act on consistently and repeatedly.

From the above interpretation, we can say that values are something as 'good'. Like good behavior, good attitude, good human being, good attributes, etc. good values means plenty in our life. They help us to evolve better and gain success in our life. They make us compassionate about things which is a very important part of good values. Good values also make us insight which helps in studies, efforts, hard work are the main factors of a successful life. They are vital for progress in life.

Moral values are set of practices guiding us to evaluate what is good or bad, what is right or wrong. Moral values facilitate us to form the character and personality. Moral values not only show our personality, but also represent our family in a society where we are living. Moral values such as compassion, generosity, kindness, politeness, self-control, honesty, loyalty, determination, respect for elders, truthfulness etc. should be inherited by every person. Moral values are helping us to improve our decision making power. Individuals who possess good moral values are considered to be an asset to the society. They do not only lead a harmonious, disciplined life, but also helps in bringing out the best in those around them. Their workability, sense of self monitoring and serving nature is appreciated by everybody.

VI. Role of institution to inculcate moral values among children

In ancient India, education was imparted through 'Gurukul' as 
an institution where education was given with emphasis on moral values. In this era education has created several new field of education and educational technology has emerged, but nothing serious work has done about teaching morality. The educational institution is placed to make children perfect with learning experience which relate to the challenges of their everyday lives. An institution must give emphasis on all round development of children including moral development. They must focus on organizing various social activities with all social groups which cater to children and this should include parents and community groups. Institutional rules and regulation, the relationship between teaching and non teaching staff must be led by democratic principles which helps with the adoption of positive values. The institution also responsible for keeping clean, beautiful environment on campus. The institution should protect various social evils such as smoking, drinking, ragging in the campus. The role of the institution is to provide an environment in which children always fostering with good positive values.

\section{Role of teacher to inculcate moral values among children}

The teacher should help children to realize that they are the future of the nation. Teachers always make awareness in children about how lack of humanity, honesty, materialistic life would dangerous for national development. Teaching moral values should be one of the important part of teaching in any educational institution to promote individual and social welfare. Role of the teacher in the institution in inculcating values among children becomes important. The teachers have to reflect various moral values such as honesty, integrity, justice in his behavior. Therefore, teachers must possess good moral values and a better person because personality of teachers makes the deepest impression on a student. To promote values teachers should arrange value oriented programming like drama in the classroom. Teachers must try to draw motivation in students to participate in co-curricular activities, NSS programmed, social work, physical activities like game, sports, yoga and cultural activities for promoting moral values. Participation in cultural activities will make the student aware of rich culture and heritage. Teachers give advice on many issues related to character and values.

\section{Role of curriculum to inculcate moral values among children}

The object of education is to turn the eye, which the soul already possesses to the light. The complete function of education is not only to put knowledge into the self, but also to evolve the best things that are dormant in the soul, and to do so by directing it to the right objects. The trouble of schooling, then, is to provide it the proper surroundings. (Plato's Republic, Book vii, 518)

From the above viewpoint of Plato, we can understand that value education is important for drawing out the best things in children. The curriculum is considered as a set of learning experience as provided to the students for their all round development. So we need a value oriented curriculum. Therefore, in educational organization ethical part have to encompass in the curriculum. Co-curricular activities like painting, music, fine arts, recitation would be an important part of curriculum which helps to develop human quality of love. Problem based learning, group discussion; working in group etc should take place in curriculum as provide opportunities for student interaction to each other as well. Environmental education should take place in the curriculum in order to inculcate good habits like cleanliness, peacefulness etc.

\section{Role of parents to inculcate moral values among} children

Parents are considered founder of moral values in their children. Family is the first institute for a child to learn behavior. So parents are vital in moral development because they are the first teacher and role models. They have helped their children to gain knowledge about what is good or bad, what is right or wrong by giving various example. They assist to be acquainted with social norms. Parents inculcate values in their children by telling moral stories, biography of great philosophers and giving opportunities to interact with their neighbors. Children should create a play group among their age groups by which they can develop we feeling. Parents should narrate patriotic, religious or ethical stories. Parents help to learn to be polite, respectful and considerate towards others. They can involve their children in community service that generate an attitude of serving because caring is an important moral value.

\section{CONCLUSION}

It is known to everyone that moral value is the main pillar to build a peaceful, harmonious and healthy life of a human being. Moral development of children can be formed through proper education, formal, non-formal or informal. Each aspect of education depends on the role of Parents, institution, Teachers, curriculum, environment, etc. This article focuses on this major role and described briefly what role should have.

\section{REFERENCES}

1. Aggarwal, J.C.(2005). Education for values, Environment and Human Rights. Shipra Publications, New Delhi.

2. Bhardwaj, Deepshikha; Tyagi, Harish Kumar \& Ameta, Dr. Devendra (2015). A Study on the Role of School Curriculum and Teachers in Inculcation of Values among Elementary School Students. Journal of Education and Practice, ISSN 2222-1735 (Paper) ISSN 2222-288X (Online),Vol.6,No.31,2015

3. Dulama, Maria Eliza; Iovu, Mihai-Bogdan \& Alexandru Marius Bodochi Ursu (2011). Developing Values for Secodary School Students through the Study of Art Ojects. Acta Didactica Napocensia, Volume 4, numer 2-3, 2011

4. Kaur, Dr. Ripenjeet (2015). Value education at school level. A Biannual Peer Reviewed Refereed International Journal of Multidisciplinary \& Contemporary Researches Vol. I, Issue I, June 2015, pp. 29-33

5. Nucci, L. P. (2006). Education for moral development. In M. Killen \& J. G. Smetana (Eds.), Handbook of moral development (pp. 657-681). New Jersey: Lawrence Erlbaum Associates.

6. Robert Thornberg and Ebru $O$ uz (2013). Teachers' views on values education: A qualitative study in Sweden and Turkey, 2013. International Journal of Educational Research, (59), 1,49-56.

7. Samantaray, Jayashree (2008). Inculcation of Values through Education. Edutracks, 7(12)

8. Singh, Amardeep (2011). Evaluating the Impacts of Value Education: Some Case Studies. International Journal of Educational Planning \& Administration, Volume 1,Number 1 (2011),pp. 1-8

9. Sivanithi, K., Vennila, G. (2013). Promoting Peace Through Peace and Value Education in the Trend of Globalization. International Journal of Teacher Educational Research (IJTER) Vol.2 No.1 January,2013 ISSN:2319-4642

10. Taylor, M. (2006). The development of values through the school curriculum. In R. H. M. Cheng, J. C.K. Lee \& L. N. K.Lo (Eds.), Values education for citizens in the new century (pp. 107-131). Sha Tin:The Chinese University Press.

11. https://blog.essaybasics.com/if-character-is-lost-everything-is-lostspeech-sample/

12. https://brainly.in/question/1057764

13. https://www.scribd.com/document/152025491/Values

14. https://research-education-edu.blogspot.com/2008/11/plato-andeducation.html

15. https://educheer.com/essays/plato-thought-on-education/ 